\title{
Effects of Board Game on Speaking Ability of Low-proficiency ESL Learners
}

\author{
Yong Mei Fung (Corresponding author) \\ Department of English Language, Faculty of Modern Languages and Communication \\ Universiti Putra Malaysia, 43400 Serdang, Selangor, Malaysia \\ E-mail: yong@upm.edu.my \\ Yeo Li Min \\ Department of English Language, Faculty of Modern Languages and Communication \\ Universiti Putra Malaysia, 43400 Serdang, Selangor, Malaysia \\ E-mail:1m_yeo@yahoo.com
}

Received: 01-12-2015

Published: 01-05-2016
Accepted: 05-03-2016

doi:10.7575/aiac.ijalel.v.5n.3p.261
Advance Access Published: March 2016

URL: http://dx.doi.org/10.7575/aiac.ijalel.v.5n.3p.261

The research is financed GIPP Vot 9323642.

\begin{abstract}
ESL learners often experience anxiety and feel uncomfortable when speaking in the target language. This paper examines the anxiety level of polytechnic students when speaking English and the effects of board game on their speaking performance. The participants were selected from two intact classes which were randomly assigned into experimental and control groups comprising 30 students each. Data were obtained from pre- and post-treatment speaking tests and questionnaire. The questionnaire measuring anxiety factors was adapted from Yaikhong and Usaha (2012) and Woodrow (2006). The board game "What Say You" employed during the treatment was a speaking activity which required players to speak on a topic within a given time frame. The experimental group played the board games over six sessions. The results from the experimental and control groups showed significant difference in the pre- and post-treatment speaking test scores. However, the speaking performance of the experimental group revealed significantly higher scores. Students who were initially hesitant and passive were more willing to speak and were able to present and justify their ideas more confidently as compared to the control group after the treatment. The findings reveal that the board game is a useful tool to engage learners' participation in class and to enhance the speaking ability of low-proficiency ESL learners.
\end{abstract}

Keywords: anxiety level, board game, speaking ability, low-proficiency students, ESL learners

\section{Introduction}

Learning to speak and communicate are major aims for learning English (Nunan 2003; Richards \& Renandya 2002). Students sometimes need to go extra miles to acquire extended exposure and to use the language in real life in order to be competent in the language (Davies \& Pearse, 2000). However, some learners feel anxious and uncomfortable when speaking in the target language for fear of making mistakes (Nascente, 2001). As such, they become very cautious and lack self-confidence whenever they speak in the target language.

Insufficient teaching hours for English is a main factor that hinders teachers from putting effort in improving learners' speaking and listening skills apart from teachers' lack of knowledge and skills (Chang \& Goswami, 2011; Chen \& Goh, 2011). Furthermore, big class sizes (Aduwa-Ogiegbaen \& Iyamu, 2006; Byun et al., 2010; Chang \& Goswami, 2011; Chen \& Goh, 2011), students' poor proficiency (Chang \& Goswami, 2011; Chen \& Goh, 2011), insufficient facilities and equipment (Aduwa-Ogiegbaen \& Iyamu, 2006; Chen \& Goh, 2011), and learning in a non English-speaking environment (Chang \& Goswami, 2011; Chen \& Goh, 2011) contribute to the factors of inadequate emphasis on speaking in the classroom.

In Malaysia, students spent at least 11 years learning English before entering tertiary education. However, many still lack mastery of the language skills and perform poorly in class and outside the class. Many graduates inadequate ability to communicate well in English are said to lead to poor employability (Yahaya, Yahaya \& Ismail, 2011).

The challenges in education emerge from the examination-oriented teaching and learning process . This is supported by Lee (2012) who agrees that the education system in Malaysia is not only very examination-oriented but also lacks creativity. He added that being too dependent on examination does not reflect the ability and understanding to use the language entirely as speaking is not tested per se. Choy and Troudi (2006) believe that there is a need to change the perception of students because many Malaysian students find learning English dreadful and boring as English does not play a part in their lives outside of school. 
Speaking requires students' participation in classroom's oral tasks, yet the inconsistency between class and course goals obstruct their opportunities for real practice (Derakhshan, Tahery, \& Mirarab, 2015). Teachers and students tend to spend class time on practising tasks for form-based examinations instead of focussing on activities to improve students' communicative competence (Chang \& Goswami, 2011; Gao, 2012; Pan \& Block, 2011).

One way to increase the use of the second language is to include language games in learning activities, such as board games to stimulate students' interest in speaking and to enhance proficiency. According to Kapp (2012), games are interactive because players interact with other players during the game, in accordance to the game system and also with the context presented during the game. Kapp further asserts that the influence of games is fast becoming a trend for learning and interactive learning experiences.

Board games are not just free-flow but contain a particular context that is usually "structured" and "rule-governed" (Smith, 2006). Lee (2012) argues that if board games are aligned with the national curriculum and matched with specific learning objectives, implementing board games can be effective and meaningful teaching tool when players learn and generate chunks of language from the games. Learners can practise all the language skills and types of communication through games (Ersoz, 2000). Board games also promote turn-taking skill among the players (Smith, 2006). Turn-taking allows every player to let each and everyone a chance to play equally and learn how to play as a team. This skill creates a learning environment that incorporates the elements of cooperative learning, competition, excitement, curiosity and creativity (Arslan, Moseley, \& Cigdemoglu, 2011).

As the benefit of using games in the classroom is supported by literature, this study, therefore, seeks to investigate the effects of using a board game "What Say You" in reducing speaking anxiety and improving speaking performance of low-proficiency students.

\subsection{Objectives}

The objectives of this study are to ascertain students' level of speaking anxiety and the effect of board games on the speaking performance of low-proficiency ESL students. The study is guided by the following research questions.

1) What anxiety level do low-proficiency ESL students experience when they speak in English?

2) What is the effect of board games on the students' speaking ability?

\subsection{Theoretical Framework}

The theoretical framework of the study is guided by the input-process-output model (see Figure 1).

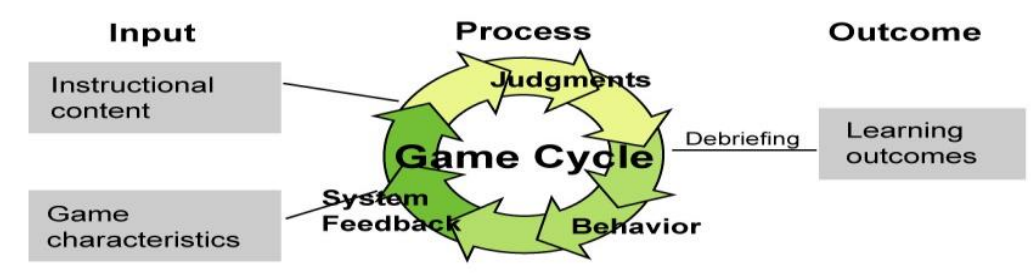

Figure1. The Input-Process-Output Model by Garris, Ahlers and Driskel (2002)

This input-process-output model was developed by Garris, Ahlers and Driskel (2002). The game model enables learners to practise speaking through games and also to look at the effectiveness of the games through the learning outcomes, namely, speaking performance. The implementation of the board game based on this model comprises three domains: input, process and output.

The input domain is the planning stage that determines the type of instructional content to be integrated. In this study, the instructional content refers to the board game. The mode of the games can be fun yet challenging as it is adaptable to suit the learners' level. Nevertheless, learners have to adhere to the rules agreed upon in order to complete the games. The input domain also includes the games characteristics in relation to speaking that correspond with the learning outcomes. It also decides which information from the game-play is used for assessment.

While learners play the board game, they will experience a process called the "Game Cycle", which is shown in the model's process domain. This domain includes user judgments or reactions, user behaviour, and system feedback or reflection. User judgment refers to the individual judgment that learners make about the game which includes interest, enjoyment, confidence, and task involvement.

User behaviour is the manner the learner reacts to the game such as greater persistence or time that is given to complete the task. One of the keys characteristic of game play is that learners will not play and stop a game immediately but will play repeatedly when they are engaged, engrossed and addicted (Garris et al., 2002).

The next process is the system feedback that continues to motivate players. Embedded formative assessment (scores) is also integrated into the game cycle. The formative assessment can also take the form of constructive feedback from peers and instructors.

The link between the game-cycle and learning objectives is represented by debriefing, or reviewing and reflecting on student's presentation to ensure the purpose of the game meets the learning objectives. The debriefing is to help 
students to improve and apply speaking skills appropriately in line with the course syllabus, that is, to involve in a group discussion and do a short oral presentation.

\section{Method}

This study employs a quasi-experimental research design to determine whether the use of board games has an effect on low-proficiency students' speaking ability. The independent variable was the "What Say You" board game while the dependent variable was the speaking performance. Two intact classes were selected to be participants in the study. The classes were randomly assigned into experimental and control groups.

\subsection{Participants}

The participants for this study involved 60 first-year students from Polytechnic Melaka. The students shared similar background and characteristics in terms of age, educational background, level of English proficiency and speaking ability. All of them were 18 years old. They were all Malay students except for three Indians. They achieved a passing grade ranging between $\mathrm{C}+$ and $\mathrm{C}$ in SPM English. Almost all of them could not converse well in English and were afraid of making mistakes.

They were enrolled in a communicative English course. The course focuses on helping students to improve their communication ability to speak on current issues or topics of interest and application of effective presentation skills. The students met for three contact hours per week over 16-week duration.

The experimental group comprised 30 students majoring in International Business. The other 30 students majoring in Accounting formed the control group. Both groups were taught by the same lecturer. This was to minimize potential impact on the participants' outcome as varying teaching styles of different lecturers might affect the findings of the study.

\subsection{Research Instruments}

\subsubsection{Questionnaire}

The questionnaire for this study comprised two parts: part 1 consisted 9 items and part 2 consisted 27 items. The first part of the questionnaire on how anxious students feel when speaking English within and outside classroom was adapted from Woodrow (2006) with a five-point Likert scale ranging from 1 (not at all anxious) to 5 (extremely anxious). The second part of the questionnaire on Second Language Speaking Anxiety Scale was adapted from Yaikhong and Usaha (2012) which they had adopted from the Foreign Language Classroom Anxiety Scale (FLCAS) by Horwitz, Horwitz \& Cope (1986). Each item was answered with a five-point Likert scale, ranging from 1 (strongly agree) to 5 (strongly disagree). The questionnaire was administered to all 60 participants before the pre-treatment speaking test. To test the internal consistency of the items in the questionnaire, the Cronbach's alpha set at .05 was used as the indicator. The Cronbach's alpha for Part 1 was .896 while the Cronbach's alpha for Part 2 was .77. Both obtained reliability values of more than 0.70 , which shows that all the items were reliable.

\subsubsection{Speaking tests}

Pre-treatment and post-treatment speaking tests were administered to the participants. The purpose of the speaking tests was to measure students' speaking performance before and after the treatment. Each of the participants was given a topic at random. The topic given to each individual was the same for both pre-test and post-test. There were altogether eight topics. Four of them were adapted from the list of topics used in students' group discussion while another four were adapted from the board game. The participants were given one minute to prepare and two minutes to speak on the topic. Besides the researcher, one independent inter-rater was asked to grade the students' speaking performance. In order to ensure reliability and the consensus that had been drawn between the two raters, intra-class correlation coefficient (ICC) was calculated to measure the degree of agreement. The results indicated perfect agreement between the raters $(\mathrm{ICC}=0.98)$ for pre-treatment and $(\mathrm{ICC}=0.968)$ for post-treatment speaking test scores.

\subsubsection{Board Game}

The board game "What Say You" consists of a board whereby players can spin to decide on the category to speak on. There are six different categories which come together with decks of cards, namely Picture This, What's Your View, One Word Card, Sentence Level, Choose One, and Wild Card. The front of the card shows the card category. Topic description either in the form of a word, a phrase, a picture or sentence is shown on the opposite side of the card. The topics comprise different themes such as social issues, health, science and technology, and situational issues (see Appendices A and B).

\subsection{Data Collection Procedure}

Before the actual experiment was conducted, the participants in the experimental group were informed about the rules of the game. A demonstration of how to play the board game was carried out with the help of three volunteers from the class. The students were divided into three groups of ten members each. The instructor reminded them that each student should have a chance to participate in the game. The class spent approximately 45 to 55 minutes to complete three rounds of game categories including debriefing in each session.

They played the board game twice a week. The researcher took the last 20 minutes of class time to conduct the game. As students were very much into the game, they did not mind extending the class time. The experimental group played three game cycles over three weeks. Each game cycle was completed within one week. 
To kick start the first game cycle, every group identified the first representative/player for the game. The first representative went to the front and spun the board to determine the category. After that, he or she would pick a card at random from the deck of cards according to the category. The representative was given one minute to prepare what to say and spent the next two minutes to present his or her ideas based on the topic. Then, the next player from the second group would go through the same process followed by the third group. This went on till they had completed three rounds of game categories. Marks were given based on language, content and delivery. Upon the completion of the first game cycle, a debriefing session was held to give the scores and also to provide feedback on the players' performance, errors made and suggestions for improvement.

However, slight changes were made to the rules and regulations for the second game cycle. The changes were to ensure that all three representatives for each round would have the same card category to ensure fairness. Before the game began, the cards in each category were arranged according to their level of difficulty. The first player who spun the board would pick the first card for the category. Subsequently, the other two players would pick a card from the same pile. They were not allowed to choose the card randomly but to take the card on the top. The player would flash the card to his or her group members and discuss verbally what to include in the presentation. The same process was applied for the remaining categories.

From observation, some of the students were unable to continue their presentation due to poor command of English and did not have much to talk about despite getting help from group members. Hence, adjustment was made in the last cycle of the game to allow the groups to jot down the points discussed. The duration for preparation and presentation was extended for another minute. The changes were made to help the weak students to gather more points to present within the time allocation. The players were expected to speak more as the week progressed because they had learned how to improve their presentation from the debriefing sessions.

In order not to deprive the control group of the game experience, they were given the opportunity to play two rounds of the board game.

\section{Results \& Discussion}

For the analysis of the quantitative data, SPSS Version 20.0 is used. The percentages and descriptive statistics are calculated and discussed to answer research questions 1. Paired sample t-test is calculated to compare two sets of scores within the experiment and control groups while independent sample t-test is computed to compare the sets of posttreatment speaking scores between the two groups to address research question 2.

It is important to find out about the students' anxiety level at the initial stage. Each item in the questionnaire expresses a degree of anxiety with a Likert-type scale ranging from 1 - 5: not at all anxious, slightly anxious, moderately anxious, very anxious and extremely anxious respectively (see Table 1 ).

The results revealed that $61.7 \%$ of the participants were moderately anxious when responding verbally to lecturer's question in class (item 1), $23.3 \%$ of the participants were slightly anxious, and $11.7 \%$ were not at all anxious. A total of $48.3 \%$ of the participants faced moderate anxiety while taking part in a group discussion in class (item 3), whereas $21.7 \%$ were very anxious, and $18.3 \%$ were slightly anxious. However, $46.7 \%$ of the participants were very anxious while taking part in role-play or dialogue in front of class (item 4) while $36.7 \%$ were moderately anxious.

Table 1 shows that the percentage of giving an oral presentation to the rest of the class (item 5) was similar to the percentage of taking part in group discussion in class (item 3), both recorded at $48.3 \%$ respectively. However, the level of anxiety was different. Participants were very anxious while giving an oral presentation whereas they were slightly anxious while taking part in group discussion. This reflects that the participants encountered higher anxiety when they were required to stand in front of the class to carry out an oral presentation. In the context where participants were asked to contribute in formal discussion in class (item 6), more than half of the participants, that is $58.3 \%$ were moderately anxious, $21.7 \%$ were very anxious as compared to $11.7 \%$ who were less anxious. The participants were not prepared to participate in a formal discussion because of their limited knowledge on the subject matter and lack of confidence to argue their points due to their poor command of English. They were also very fearful of making grammatical mistakes or giving irrelevant points in their justifications that might lead to embarrassment.

Four items in the questionnaire were about anxiety encountered outside the classroom. About $73.4 \%$ of the participants felt moderately anxious to extremely anxious when a lecturer asked question in English (item 8). This was followed by $66.6 \%$ of the participants who experienced moderate to extreme anxiety when speaking to their English lecturer informally outside the class (item 2). A total of $68.4 \%$ recorded anxiety above average whereas $31.6 \%$ were below average when asking for advice in English from any lecturer in the polytechnic (item 9). As the participants were unable to express themselves efficiently to their lecturer in English, they avoided seeking advice from their lecturer. Advice refers to both guidance and supervision in relation to personal and academic matters. Thus, they made their own assumptions based on their understanding in the interpretation of the task instead of approaching the lecturer for clarifications. Finally, about $63.4 \%$ of the participants were moderate and extremely anxious having to start a conversation in English with a friend (item 7) while 36.7\% were below the moderate level of anxiety. The participants felt anxious because they were so used to conversing in Malay language all the time. Speaking in Malay provides a sense of security (Butzkamm, 2003). Moreover, the institution environment does not provide much opportunity to speak in a second language, as conversing in the Malay language facilitates easy understanding among them.

The results for speaking anxiety within the classroom from the questionnaire indicated that participants were most anxious when giving an oral presentation and taking part in role play in front of the class. These results are similar to 
the findings of Woodrow (2006) which revealed that anxiety could affect students' English oral communication undesirably, specifically having to perform in front of the class or communicating with teachers. Woodrow's (2006) findings showed that taking part in group discussion was rated the lowest, contrary to the results which revealed that starting a conversation out of class in English with a friend was the least anxious situation. This is due to a more relaxing environment speaking English to a friend outside the classroom. Furthermore, a friend usually does not correct the English mistakes as long as he or she is able to comprehend the message conveyed.

In sum, anxiety is developed because of poor proficiency in the second language and the context encountered in learning (Du, 2009). Students hold negative perception that they will perform poorly due to their language proficiency compared to those who are more competent in speaking (Kitano, 2001). Hence, it is crucial to determine learning situations where students are prone to anxiety which might impact the extent of students' involvement in learning a second language in the classroom (Brown, 2009). Students who are able to overcome anxiety will engage in the learning activities and facilitate the process of learning.

Table 1. Participants' speaking anxiety level within and outside the classroom $(n=60)$

\begin{tabular}{|c|c|c|c|c|c|c|c|c|}
\hline No. & Item & 1 & 2 & 3 & 4 & 5 & $\begin{array}{l}\text { Mea } \\
\text { n }\end{array}$ & SD \\
\hline 1 & $\begin{array}{l}\text { Responding verbally to my lecturer's question in } \\
\text { class. }\end{array}$ & 11.7 & 23.3 & 61.7 & 1.7 & 1.7 & 2.58 & 0.787 \\
\hline 2 & $\begin{array}{l}\text { Speaking informally to my English lecturer out of } \\
\text { class. }\end{array}$ & 5 & 28.3 & 55 & 8.3 & 3.3 & 2.77 & 0.81 \\
\hline 3 & Taking part in a group discussion in class. & 6.7 & 18.3 & 48.3 & 21.7 & 5 & 3 & 0.939 \\
\hline 4 & $\begin{array}{l}\text { Taking part in role-play or dialogue in front of } \\
\text { class. }\end{array}$ & 6.7 & 6.7 & 36.7 & 46.7 & 3.3 & 3.33 & 0.914 \\
\hline 5 & Giving an oral presentation to the rest of the class. & 5 & 8.3 & 38.3 & 48.3 & 0 & 3.33 & 0.83 \\
\hline 6 & $\begin{array}{l}\text { When asked to contribute to a formal discussion in } \\
\text { class. }\end{array}$ & 6.7 & 11.7 & 58.3 & 21.7 & 1.7 & 3 & 0.23 \\
\hline 7 & $\begin{array}{l}\text { Starting a conversation out of class with a friend } \\
\text { who speaks English. }\end{array}$ & 20 & 16.7 & 61.7 & 0 & 1.7 & 2.47 & 0.873 \\
\hline 8 & $\begin{array}{l}\text { A lecturer in the polytechnic asks me a question in } \\
\text { English. }\end{array}$ & 6.7 & 20 & 50 & 21.7 & 1.7 & 2.92 & 0.869 \\
\hline 9 & $\begin{array}{l}\text { Asking for advice in English from a lecturer in my } \\
\text { polytechnic. }\end{array}$ & 13.3 & 18.3 & 51.7 & 15 & 1.7 & 2.73 & 0.936 \\
\hline
\end{tabular}

In the second part of the questionnaire, there were 27 items to elicit participants' opinions on speaking anxiety based on a Likert-type scale ranging from 1 - 5: strongly disagree, disagree, neutral, agree, and strongly agree respectively (see Table 2).

The results discussed the constructs in the questionnaire, namely, comfort in using English, fear of negative evaluation, communication apprehension, and test anxiety. There were seven items pertaining to the construct of feeling uncomfortable in using English (items, 1, 2, 5, 10, 15, 19, and 27). Out of the 7 items, 50\% of the participants agreed that they felt less comfortable and trembled when knowing they were going to be called on to speak in English (item 2). Next, $40 \%$ of the participants agreed that they felt anxious while waiting to speak English (item 15), followed by $33.3 \%$ who agreed that they never felt quite sure of themselves while speaking English (item 1). The participants stated that when they were asked to speak in English, they did not know what to say and they felt nervous.

Five items were about feeling comfortable when using in English (items 8, 11, 12, 24, and 26). Of the total, 35\% of the participants disagreed with the statement "I have no fear of speaking English" (item 8) which shows that they encountered anxiety. There is a correspondence between with item 2 in which $50 \%$ agreed they trembled when called upon and item 12 whereby 55\% did not agree that they enjoyed the experience of speaking English.

Next, the fear of having negative evaluation element was elicited in 4 items (items 4, 6, 7 and 20). For item 6, a total of $45 \%$ participants showed disagreement that they were afraid that others would laugh at them while speaking English. Participants who are not proficient in English would typically be worried of their friends' judgment, hence, reducing participation in those activities as shown in Aida's study (1994). However, it is not true for the participants in this study because they are familiar with their peers; thus, it does not affect them when they have to speak in front of the class or afraid of being laughed at. They do not feel inhibited or pressured as their level of proficiency in the language are almost similar.

The element of communication apprehension was elicited in 8 items (items 3, 9, 14, 17, 21, 22, 24, and 27). Both items 3 and 9 indicated that participants disagreed about forgetting things they knew $(36.6 \%)$ and heart pounding due to nervousness $(50 \%)$ but agreed that their bodily reaction demonstrated fear. $45 \%$ of the participants agreed that their body felt tense and rigid while speaking in English (item 14), 40\% agreed that they disliked using their voice and body expressively (item 17), while another $35 \%$ agreed to have trouble coordinating movements when speaking English. 
Finally, items 13 and 23 were about test anxiety. From the results, $36.7 \%$ of the participants were neutral while $48.3 \%$ agreed that there was anxiety when there were more speaking tests whereas $53.3 \%$ were neutral. In terms of the number of rules they had to learn to speak English, $40 \%$ felt anxiety. The items show almost half of the overall participants agreed that test and rules caused anxiety. The findings above corroborate with Horwitz et al.'s (1986), Young's (1990) and Koch and Terrell's (1991) findings that activity in the classroom with a high self-exposure requirement is most stressful for L2 learners. This is because the participants would form some impression of how others would judge them during their presentation.

Table 2. Participants' opinions of their speaking anxiety $(n=60)$

\begin{tabular}{|c|c|c|c|c|c|c|c|c|}
\hline No. & Item & 1 & 2 & 3 & 4 & 5 & Mean & SD \\
\hline 1 & $\begin{array}{l}\text { I never feel quite sure of myself while I am } \\
\text { speaking English. }\end{array}$ & 6.7 & 16.7 & 43.3 & 23.3 & 10 & 3.13 & 1.033 \\
\hline 2 & $\begin{array}{l}\text { I tremble when knowing that I am going to be } \\
\text { called on to speak English. }\end{array}$ & 0 & 30 & 20 & 35 & 15 & 3.35 & 1.071 \\
\hline 3 & $\begin{array}{l}\text { In a speaking class, I can get so nervous I forget } \\
\text { things I know. }\end{array}$ & 8.3 & 28.3 & 40 & 20 & 3.3 & 2.82 & 0.962 \\
\hline 4 & $\begin{array}{l}\text { I feel very self-conscious while speaking English } \\
\text { in front of other students. }\end{array}$ & 1.7 & 25 & 50 & 20 & 3.3 & 2.98 & 0.813 \\
\hline 5 & $\begin{array}{l}\text { I get nervous and confused when I am speaking } \\
\text { English. }\end{array}$ & 3.3 & 28.3 & 43.3 & 21.7 & 3.3 & 2.93 & 0.88 \\
\hline 6 & $\begin{array}{l}\text { I am afraid that other students will laugh at me } \\
\text { while I am speaking English. }\end{array}$ & 13.3 & 31.7 & 36.7 & 11.7 & 6.7 & 2.67 & 1.068 \\
\hline 7 & $\begin{array}{l}\text { I get so nervous when the language teacher asks } \\
\text { me to speak English which I have prepared in } \\
\text { advance. }\end{array}$ & 5 & 31.7 & 46.7 & 13.3 & 3.3 & 2.8 & 0.865 \\
\hline 8 & I have no fear of speaking English. & 1.7 & 33.3 & 31.7 & 26.7 & 6.7 & 3.03 & 0.974 \\
\hline 9 & $\begin{array}{l}\text { I can feel my heart pounding when I am going to } \\
\text { be called on. }\end{array}$ & 5 & 45 & 30 & 13.3 & 6.7 & 2.72 & 0.993 \\
\hline 10 & $\begin{array}{l}\text { It embarrasses me to volunteer to go out first to } \\
\text { speak English. }\end{array}$ & 3.3 & 26.7 & 38.3 & 21.7 & 10 & 3.08 & 1.013 \\
\hline 11 & $\begin{array}{l}\text { I face the prospect of speaking English with } \\
\text { confidence. }\end{array}$ & 5 & 8.3 & 48.3 & 31.7 & 6.7 & 3.27 & 0.899 \\
\hline 12 & I enjoy the experience of speaking English. & 20 & 35 & 30 & 8.3 & 6.7 & 2.47 & 1.112 \\
\hline 13 & $\begin{array}{l}\text { The more speaking tests I have, the more } \\
\text { confused I get. }\end{array}$ & 3.3 & 11.7 & 36.7 & 15 & 33.3 & 3.63 & 1.164 \\
\hline 14 & $\begin{array}{l}\text { Certain parts of my body feel very tense and rigid } \\
\text { while speaking English. }\end{array}$ & 0 & 15 & 40 & 35 & 10 & 3.4 & 0.867 \\
\hline 15 & I feel anxious while waiting to speak English. & 3.3 & 11.7 & 45 & 33.3 & 6.7 & 3.28 & 0.885 \\
\hline 16 & $\begin{array}{l}\text { I want to speak less because I feel shy while } \\
\text { speaking English. }\end{array}$ & 3.3 & 15 & 38.3 & 33.3 & 10 & 3.32 & 0.965 \\
\hline 17 & $\begin{array}{l}\text { I dislike using my voice and body expressively } \\
\text { while speaking English. }\end{array}$ & 6.7 & 20 & 33.3 & 20 & 20 & 3.27 & 1.191 \\
\hline 18 & $\begin{array}{l}\text { I have trouble to coordinate my movements while } \\
\text { speaking English. }\end{array}$ & 3.3 & 20 & 41.7 & 18.3 & 16.7 & 3.25 & 1.068 \\
\hline 19 & $\begin{array}{l}\text { I find it hard to look the audience in my eyes } \\
\text { while speaking English. }\end{array}$ & 3.3 & 35 & 41.7 & 3.3 & 16.7 & 2.92 & 1.096 \\
\hline 20 & $\begin{array}{l}\text { Even if I am very well-prepared I feel anxious } \\
\text { about speaking English. }\end{array}$ & 3.3 & 21.7 & 48.3 & 23.3 & 3.3 & 3.02 & 0.854 \\
\hline 21 & $\begin{array}{l}\text { I keep thinking that other students are better at } \\
\text { speaking English than I. }\end{array}$ & 25 & 33.3 & 35 & 0 & 6.7 & 2.3 & 1.062 \\
\hline 22 & $\begin{array}{l}\text { I always feel that the other students speak English } \\
\text { better than I do. }\end{array}$ & 26.7 & 41.7 & 28.3 & 3.3 & 0 & 2.08 & 0.829 \\
\hline 23 & $\begin{array}{l}\text { I feel overwhelmed by the number of rules I have } \\
\text { to learn in order to speak English. }\end{array}$ & 3.3 & 36.7 & 53.3 & 3.3 & 3.3 & 2.67 & 0.752 \\
\hline 24 & $\begin{array}{l}\text { I don't worry about making mistakes when } \\
\text { speaking English in English class. }\end{array}$ & 6.7 & 16.7 & 43.3 & 33.3 & 0 & 3.03 & 0.882 \\
\hline 25 & $\begin{array}{l}\text { During discussion in English class, I find myself } \\
\text { thinking about things that have nothing to do with } \\
\text { the course. }\end{array}$ & 0 & 6.7 & 51.7 & 31.7 & 10 & 3.45 & 0.769 \\
\hline 26 & $\begin{array}{l}\text { I don't feel pressure to prepare very well in a } \\
\text { speaking activity for English class. }\end{array}$ & 10 & 20 & 51.7 & 16.7 & 1.7 & 2.8 & 0.898 \\
\hline 27 & $\begin{array}{l}\text { It frightens me when I don't understand what the } \\
\text { lecturer is saying in English. }\end{array}$ & 1.7 & 11.7 & 55 & 21.7 & 10 & 3.27 & 0.861 \\
\hline
\end{tabular}


To answer research question 2, comparison was made between the pre- and post-treatment speaking tests. The results revealed that the difference in the speaking scores for the experimental group was very significant. Interestingly, the number of students who obtained scores above 50 was extremely high. For the experimental group, the number of participants who scored above the 50 baseline passing mark increased from 8 to 25 participants while the control group increased from 3 to 15 participants (see Table 3). The increase in the post-test was remarkable for both groups.

The results also revealed that 5 students from the experimental group showed 20 to 25 per cent improvement in their post-treatment speaking test scores (22\% - 2 students, $24 \%$ - 2 students, $25 \%$ - 1 student, $26 \%$ - 1 student, $27 \%$ - 1 student, 29\% - 1 student), 4 students showed improvement between 26 to 30 per cent, 2 students with greater improvement of 32 per cent and 46 per cent. The results show that the board game helps to eliminate the anxiety to speak and establish positive learning among peers. Additionally, during the game cycles, students were able to have a sense of control and developed their self-confidence. A similar research conducted by Tengku Nazatul Shima and Rahmah (2012) showed that more than half (59.5\%) of the students agreed that the implementation of board game has helped the students to remember grammar rules that also contributed to self-confidence. In this study, the students displayed confidence when delivering their ideas and showed they have learned important lessons from the debriefing sessions. Students from the control group also showed improvement between 15 to 20 per cent. A total number of 7 students improved in their speaking ability (15\% - 2 students, 16\% - 2 students, $18 \%$ - 2 students and $19 \%$ - 1 student).

Table 3. Pre-treatment speaking and post-treatment speaking scores for experimental and control groups ( $\mathrm{n}=60$ )

\begin{tabular}{|c|c|c|c|c|c|}
\hline \multicolumn{3}{|c|}{ Experimental } & \multicolumn{3}{|l|}{ Control } \\
\hline Student & $\begin{array}{l}\text { Pre- } \\
\text { speaking } \\
\text { test scores }\end{array}$ & $\begin{array}{l}\text { Post- } \\
\text { speaking } \\
\text { test scores }\end{array}$ & Student & $\begin{array}{l}\text { Pre- } \\
\text { speaking } \\
\text { test scores }\end{array}$ & $\begin{array}{l}\text { Post- } \\
\text { speaking } \\
\text { scores }\end{array}$ \\
\hline 1 & 48 & 60 & 1 & 42 & 51 \\
\hline 2 & 24 & 49 & 2 & 31 & 40 \\
\hline 3 & 26 & 48 & 3 & 33 & 38 \\
\hline 4 & 54 & 62 & 4 & 54 & 65 \\
\hline 5 & 18 & 40 & 5 & 23 & 30 \\
\hline 6 & 28 & 55 & 6 & 20 & 32 \\
\hline 7 & 40 & 53 & 7 & 15 & 25 \\
\hline 8 & 54 & 71 & 8 & 25 & 40 \\
\hline 9 & 64 & 65 & 9 & 48 & 64 \\
\hline 10 & 30 & 59 & 10 & 38 & 40 \\
\hline 11 & 48 & 61 & 11 & 44 & 56 \\
\hline 12 & 56 & 67 & 12 & 48 & 56 \\
\hline 13 & 48 & 56 & 13 & 36 & 48 \\
\hline 14 & 48 & 60 & 14 & 27 & 38 \\
\hline 15 & 20 & 52 & 15 & 46 & 55 \\
\hline 16 & 40 & 57 & 16 & 42 & 52 \\
\hline 17 & 48 & 59 & 17 & 22 & 40 \\
\hline 18 & 30 & 48 & 18 & 40 & 52 \\
\hline 19 & 52 & 56 & 19 & 38 & 52 \\
\hline 20 & 44 & 54 & 20 & 43 & 58 \\
\hline 21 & 56 & 69 & 21 & 51 & 63 \\
\hline 22 & 14 & 60 & 22 & 30 & 36 \\
\hline 23 & 36 & 62 & 23 & 33 & 52 \\
\hline 24 & 36 & 62 & 24 & 26 & 35 \\
\hline 25 & 30 & 48 & 25 & 27 & 35 \\
\hline 26 & 42 & 51 & 26 & 39 & 52 \\
\hline 27 & 52 & 58 & 27 & 34 & 52 \\
\hline 28 & 68 & 72 & 28 & 30 & 38 \\
\hline 29 & 20 & 44 & 29 & 60 & 72 \\
\hline 30 & 30 & 54 & 30 & 14 & 30 \\
\hline
\end{tabular}


To find out the effect of board game on students' speaking performance, paired sample t-test was run. Table 4 shows that on the average, the students performed better in the post-treatment speaking test $(\mathrm{M}=57.07, \mathrm{SD}=7.81)$ as compared to the pre-treatment speaking test $(\mathrm{M}=40.13, \mathrm{SD}=14.32)$ for the experimental group. The students in the control group also showed improvement in the post-treatment speaking test $(\mathrm{M}=46.57, \mathrm{SD}=12.12)$ as compared with the pre-treatment speaking test $(\mathrm{M}=35.30, \mathrm{SD}=11.56)$. The class lecturer reported that students from the experimental group used more English during class discussion. They were more relaxed and more excited about working together. This is supported by Sorayaie's (2012) findings which showed that students could remember more new words and retain them better when they were applied in a relaxed and comfortable environment while playing games. In his postgame interview with the students, it was also indicated that the help from their classmates enabled them to remember words better.

Table 4. Mean within groups on pre-and post-treatment tests $(n=60)$

\begin{tabular}{|c|c|c|c|}
\hline & & Mean & Std. Deviation \\
\hline \multirow{2}{*}{ Exp. } & PreTreatment & 40.13 & 14.32 \\
\hline & PostTreatment & 57.07 & 7.81 \\
\hline \multirow{2}{*}{ Control } & PreTreatment & 35.30 & 11.6 \\
\hline & PostTreatment & 46.57 & 12.12 \\
\hline
\end{tabular}

Table 5. Normality tests for pre- and post-treatment tests

\begin{tabular}{llllllll}
\hline & & $\mathrm{N}$ & \multicolumn{2}{c}{ Std. Deviation } & Skewness & \multicolumn{3}{c}{ Kurtosis } \\
\hline \multirow{2}{*}{ Exp. } & & Statistic & Statistic & Statistic & Std. Error & Statistic & Std. Error \\
& PreTreatment & 30 & 14.23869 & -.048 & .427 & -.866 & .833 \\
\multirow{3}{*}{ Control } & PostTreatment & 30 & 7.70550 & -.059 & .427 & -.153 & .833 \\
& PreTreatment & 30 & 11.39313 & .086 & .427 & -.444 & .833 \\
& PostTreatment & 30 & 11.94436 & .168 & .427 & -.781 & .833 \\
\hline
\end{tabular}

Normality tests were tested through skewness and kurtosis to check distribution of data. "A skewness and kurtosis value between -1 and +1 is considered excellent for most psychometric purposes, but a value between -2 and +2 can be acceptable" (George \& Mallery, 2003, p. 98). Thus, since the values of skewness and kurtosis for both pre- and posttreatment tests of experimental and control groups are between \pm 2 , the data are normally distributed.

Table 6. Paired sample t-test for experimental and control groups $(n=60)$

\begin{tabular}{|c|c|c|c|c|c|c|c|c|}
\hline & & \multicolumn{4}{|c|}{ Paired Differences } & \multirow[t]{3}{*}{$\mathrm{t}$} & \multirow[t]{3}{*}{$\mathrm{df}$} & \multirow{3}{*}{$\begin{array}{l}\text { Sig. } \\
\text { tailed })\end{array}$} \\
\hline & & \multirow[t]{2}{*}{$\overline{\text { Mean }}$} & \multirow[t]{2}{*}{ Std. Deviation } & \multicolumn{2}{|c|}{$\begin{array}{l}95 \% \text { Confidence Interval of the } \\
\text { Difference }\end{array}$} & & & \\
\hline & & & & Lower & Upper & & & \\
\hline Exp. & $\begin{array}{l}\text { PreTreatment } \\
\text { PostTreatmen } \\
\mathrm{t}\end{array}$ & -16.93 & 9.91 & -20.63 & -13.23 & -9.36 & 29 & .000 \\
\hline Control & $\begin{array}{l}\text { PreTreatment } \\
\text { PostTreatmen } \\
\mathrm{t}\end{array}$ & -11.27 & 4.00 & -12.76 & -9.77 & -15.43 & 29 & .000 \\
\hline
\end{tabular}

Based on the result of the paired sample t-test, $\mathrm{t}(29)=9.36, \mathrm{p}=.000,95 \% \mathrm{CI}[-20.63,-13.23]$, it can be concluded that the treatment had a significant effect on the students' performance. Board game is a powerful tool when it is used purposefully although students may not demonstrate uniform improvement in their scores. One of the improvements is the student's fluency when delivering the task given in the post-test. For the experimental group, the test scores for student 22 , increased drastically from 14 to 60 . For student 15 , there was a very significant increase from 20 to 52 , and for student 10 there was a significant increase from 30 to 59. For the control group, the scores for student 23 increased from 33 to 52 while the scores for students 17 and 27 increased from 22 to 40 and 34 to 52 respectively.

Independent samples t-test for experimental and control groups was run to find out the significant difference of mean scores between the two groups. 
Table 7. Independent samples t-test for experimental and control groups $(n=60)$

Levene's Test for

Equality of Variances t-test for Equality of Means

95\% Confidence Interval

of the Difference

\begin{tabular}{|c|c|c|c|c|c|c|c|c|c|c|}
\hline & & $\mathrm{F}$ & Sig. & $\mathrm{t}$ & df & $\begin{array}{l}\text { Sig. } \\
\text { tailed) }\end{array}$ & $\begin{array}{l}\text { (2-Mean } \\
\text { Difference }\end{array}$ & $\begin{array}{l}\text { Std. } \\
\text { Difference }\end{array}$ & $\begin{array}{l}\text { Error } \\
\qquad \text { Lower }\end{array}$ & Upper \\
\hline $\begin{array}{l}\text { Post } \\
\text { Speaking }\end{array}$ & $\begin{array}{l}\text { Equal } \\
\text { variances } \\
\text { not } \\
\text { assumed }\end{array}$ & 8.74 & 0.004 & 3.94 & 50.33 & 0.000 & 10.47 & 2.65 & 5.14 & 15.80 \\
\hline
\end{tabular}

Table 7 shows that the participants in experimental group $(\mathrm{M}=57.07, \mathrm{SD}=7.81)$ scored higher than the control group $(\mathrm{M}=46.57, \mathrm{SD}=12.12)$. Based on the results of the independent samples t-test, $\mathrm{t}(50.33)=3.94, \mathrm{p}=.000,95 \% \mathrm{CI}$ $[5.14,15.80]$, since the significant value is less than alpha at .05 level of significance, it can be concluded that there is a significant difference between experimental and control group participants' achievement post-speaking scores. Students were able to enhance their self-confidence through games and build their sense of control. This is because when there is less pressure, they will learn something better. This finding concurs with Tengku Nazatul Shima Tengku Paris and Rahmah Lob Yussof's (2013) findings. There are many positive outcomes such as motivation to learn English, ability to use new words or structure and improvement in thinking skills.

\section{Conclusion}

The findings of this study are significant to English lecturers in the polytechnic or other institutions of higher learning and even English teachers to use board games as an alternative way to reduce learners' speaking anxiety in the classroom. When speaking anxiety is lowered, they become confident and performance will improve. Language learning becomes less stressful and enjoyable. The findings also show that the board game motivated students to speak after watching their friends' presentation and increased their confidence level when they were able to perform in subsequent game rounds and also in class activities.

There were two limitations in the study. The first limitation was the short time frame to play 18 rounds of games in three weeks. The duration allocated has to be taken into consideration in order for the players to take part more frequently. Another limitation that needs to be addressed is the number of participants in each group. In this study, there were 10 people in a group due to the constraint of space. The ideal number for each group is between four to six participants. This will offer more opportunities for students to participate in the games.

This study contributes to the field of communicative English by emphasising the usefulness of board games in developing speaking skill. Language instructors can integrate games in the classroom to establish rapport with students. In due course, students will begin to appreciate English and learn through their own exploration. Besides, board games can add diversity in classroom activities. It induces lively discussions as well as encourages creative thoughts to bounce.

\section{References}

Aduwa-Ogiegbaen, S., \& Iyamu, E. (2006). Factors affecting quality of English language teaching and learning in secondary schools in Nigeria. College Student Journal, 40(3), 495-504.

Aida, Y. (1994). Examination of Horwitz, Horwitz, and Cope's construct of foreign language anxiety: The case of students of Japanese. The Modern Language Journal, 78(2), 155-168.

Arslan, H. O., Moseley, C., \& Cigdemoglu, C. (2011). Taking attention on environmental issues by an attractive educational game: Enviropoly. Procedia-Social and Behavioral Sciences, 28, 801-806.

Brown, A. V. (2009). Students' and teachers' perceptions of effective foreign language teaching: A comparison of ideals. The Modern Language Journal, 93(1), 46-60.

Butzkamm, W. (2003). We only learn language once. The role of the mother tongue in FL classrooms: Death of a dogma. Language Learning Journal, 28(1), 29-39.

Byun, K., Chu, H., Kim, M., Park, I., Kim, S., \& Jung, J. (2011). English-medium teaching in Korean higher education: Policy debates and reality. Higher Education, 62(4), 431-449.

Chang, M., \& Goswami, J. S. (2011). Factors affecting the implementation of communicative language teaching in Taiwanese college English classes. English Language Teaching, 4(2), 3-12.

Chen, Z., \& Goh, C. (2011). Teaching oral English in higher education: Challenges to EFL teachers. Teaching in Higher Education, 16(3), 333-345.

Choy, S. C., \& Troudi, S. (2006). An investigation into the changes in perceptions of and attitudes towards learning English in a Malaysian college. International Journal of Teaching and Learning in Higher Education, 18(2), 120-130. 
Davies, P. (2000). Success in English teaching: A complete introduction to teaching English at secondary school level and above. Oxford: Oxford University Press.

Derakhshan, A., Tahery, F., \& Mirarab, N. (2015). Helping adult and young learners to communicate in speaking classes with confidence. Mediterranean Journal of Social Sciences, 6(2), 520-525.

Du. X. (2009). The affective filter in second language teaching. Journal of Asian Social Science, 5(8), 162-165.

Ersoz, A. (2000). Six games for the EFL/ESL classroom. The Internet TESL Journal, 6(6), 22-30.

Gao, L. (2012). Digital technologies and English instruction in China's higher education system. Teacher Development, 16(2), 161-179.

Garris, R., Ahlers, R., \& Driskell, J. E. (2002). Games, motivation, and learning: A research and practice model. Simulation and Gaming, 33(4), 441-467.

George, D., \& Mallery, P. (2003). SPSS for windows step by step: A simple guide and reference. 11.0 update

( $4^{\text {th }}$ ed.). Boston: Allyn \& Bacon.

Hassan, F., \& Selamat, N. F. (2002). Why aren't students proficient in ESL: The teachers' perspective. The English Teacher, 31, 107-123.

Horwitz, E. K., Horwitz, M. B., \& Cope, J. (1986). Foreign language classroom anxiety. The Modern Language Journal, 70(2), 125-132.

Kapp, K. M. (2012). The gamification of learning and instruction: Game-based methods and strategies for training and education. San Francisco: Pfeiffer.

Kitano, K. (2001). Anxiety in the college Japanese language classroom. The Modern Language Journal, 85(4), 549566.

Koch, A.S., \& Terrell, T.D. (1991). Affective reactions of foreign language students to natural approach activities and teaching techniques. In E.K. Horwitz \& D.J. Young (Eds.), Language anxiety: From theory and research to classroom implications (pp. 109-126). Englewood Cliffs, NJ: Prentice Hall.

Lee, H. (2012). SMARTies: Using a board game in the English classroom for edutainment and assessment. Malaysian Journal of ELT Research, 8(1), 1-35.

Nascente, R. (2001). Ways to deal with anxiety. English Teaching Professional, 19, 18-20.

Nunan, D. (2003). The impact of English as a global language on educational policies and practices in the Asia-

Pacific Region. TESOL Quarterly, 37(4), 589-613.

Pan, L., \& Block, D. (2011). English as a "global language" in China: An investigation into learners' and teachers' language beliefs. System, 39(3), 391-402.

Richards, J. C., \& Renandya, W. A. (2002). Methodology in language teaching: An anthology of current practice. Cambridge: Cambridge University Press.

Smith, J. H. (2006). The games economists play-implications of economic game theory for the study of computer games. Game Studies, 6(1), 1-15.

Sorayaie Azar, A. (2012). The effect of games on EFL learners' vocabulary learning strategies. International Journal of Applied and Basic Sciences, 1(2), 252-256.

Tengku Nazatul Shima Tengku Paris, \& Rahmah Lob Yussof. (2012). Enhancing grammar using board games. Procedia - Social and Behavioral Sciences, 68, 213-221.

Tengku Nazatul Shima Tengku Paris, \& Rahmah Lob Yussof. (2013). Use of 'time trap board game'to teach grammar. Procedia - Social and Behavioral Sciences, 105, 398-409.

Woodrow, L. (2006). Anxiety and speaking English as a second language. Regional Language Centre Journal, 37(3), 308-328.

Yahaya, A., Yahaya, N., \& Ismail, S. (2011). Factors contributing to proficiency in English as a second language among Chinese students in Johor Bahru. Elixir Psychology, 41, 5837-5848.

Yaikhong, K., \& Usaha, S. (2012). A measure of EFL public speaking class anxiety: Scale development and preliminary validation and reliability. English Language Teaching, 5(12), 23-35.

Young, D. J. (1990). An investigation of students' perspectives on anxiety and speaking. Foreign Language Annals, 23(6), 539-553. 
Appendix A

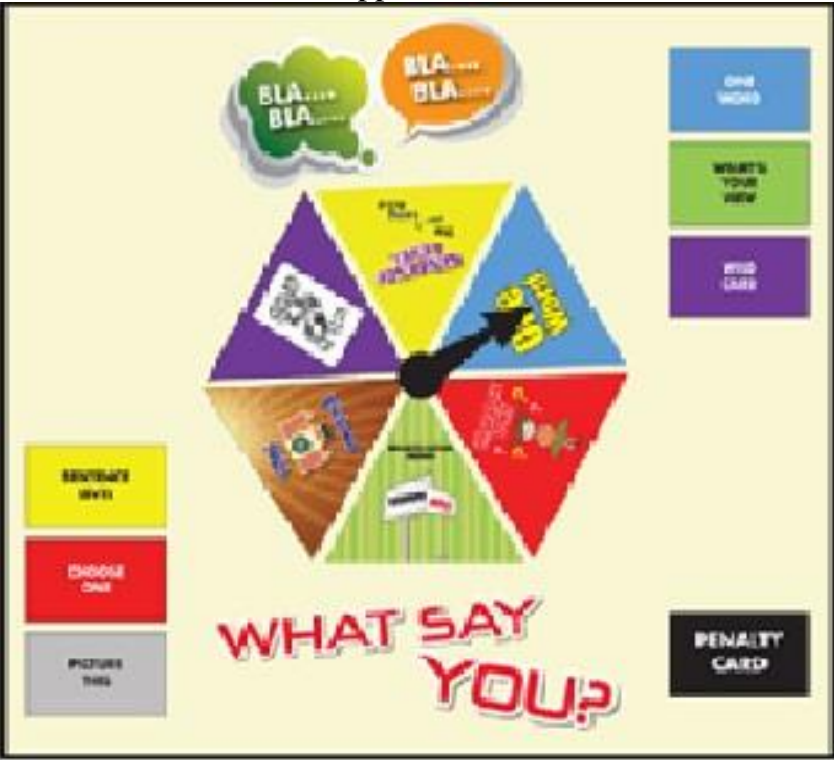

Appendix B

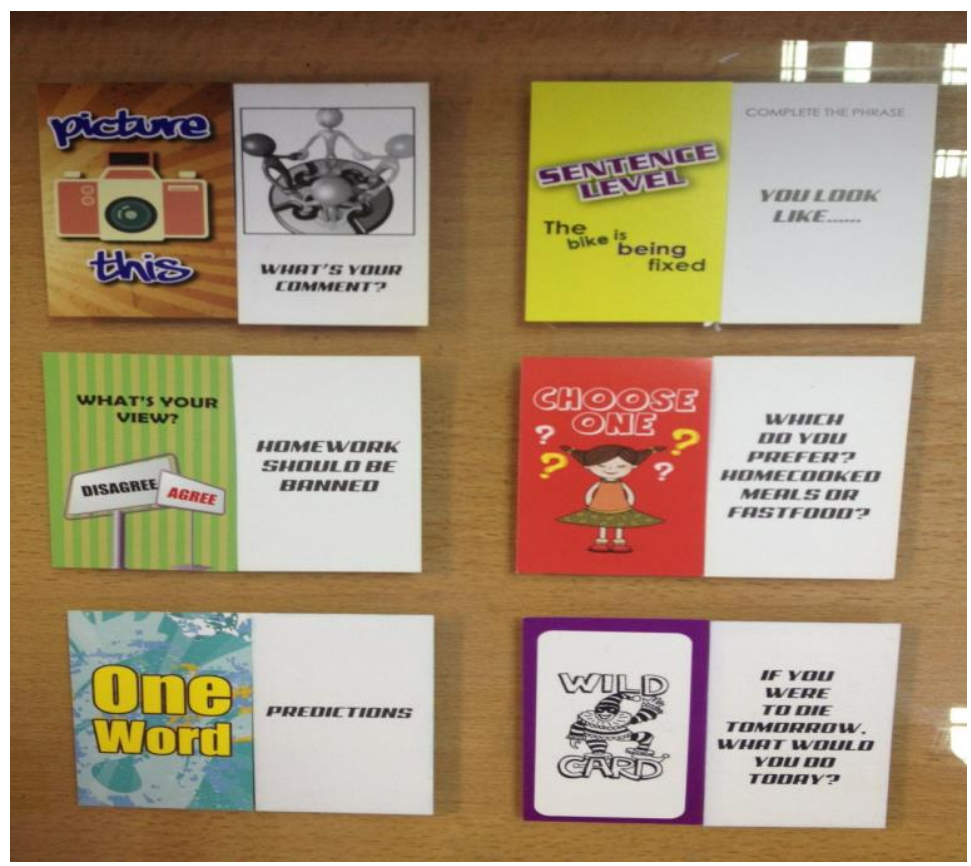

